Tropical Journal of Pharmaceutical Research December 2016; 15 (12): 2669-2673

ISSN: $1596-5996$ (print); 1596-9827 (electronic)

(C) Pharmacotherapy Group, Faculty of Pharmacy, University of Benin, Benin City, 300001 Nigeria.

All rights reserved.

Available online at http://www.tjpr.org

Original Research Article

http://dx.doi.org/10.4314/tjpr.v15i12.19

\title{
Evaluation of some toxic metals in blood samples of smokers in Saudi Arabia by inductive coupled plasma mass spectrometry
}

\author{
Mohammed A Al-Ramadi ${ }^{1}$, Fahad O Al-Otaibi ${ }^{1}$, A.M.Homoda ${ }^{2}$, Gamal AE \\ Mostafa ${ }^{2,3 *}$ \\ ${ }^{1}$ Forensic Chemistry Department, Naïf Arab University for Security Science, ${ }^{2}$ Micro-analytical Lab., Applied Organic Chemistry \\ Department, National Research Center, Dokki, Cairo, Egypt, ${ }^{3}$ Pharmaceutical Chemistry Department, College of Pharmacy, \\ King Saud University, PO Box 2457, Riyadh 11451, Saudi Arabia
}

*For correspondence: Email: gamal_most@yahoo.com

Received: 15 April 2016

Revised accepted: 11 November 2016

\begin{abstract}
Purpose: To determine some toxic elements in the blood of cigarette and tobacco pipe smokers in Riyadh, Saudi Arabia.

Methods: The study setting was Riyadh, the capital city of Saudi Arabia, Riyadh City. Male volunteers, aged 20 - 58 year, whose blood samples were collected, were classified into three groups of cigarette smokers $(N=30)$, tobacco pipe smokers $(N=30)$ and non-smokers (24). Inductive coupled plasma mass spectrometry (ICP-MS) measurement was conducted to determine the concentration of toxic metals in the blood samples after microwave acid digestion.

Results: The mean concentrations of cadmium (Cd), lead ( $\mathrm{Pb}$ ), arsenic ( $\mathrm{As})$, mercury $(\mathrm{Hg})$ and nickel (Ni) were $0.23 \pm 0.30,26.42 \pm 20.08,19.43 \pm 10.00,8.77 \pm 6.98$ and $79.57 \pm 70.51)$, respectively, for cigarette smokers; $(0.31 \pm 0.19,8.11 \pm 8.60,4.80 \pm 3.01,13.05 \pm 3.01$ and $9.96 \pm 5.00)$, respectively, for tobacco pipe smokers; and $0.07 \pm 0.20,3.89 \pm 5.82,10.09 \pm 2.75,10.44 \pm 5.37$ and $1.60 \pm 2.77$ ), respectively, non-smokers.

Conclusion: The results showed that the blood concentrations of heavy metals in smokers were higher than those in non-smokers.
\end{abstract}

Keywords: Blood, Heavy metals, Smokers, Tobacco pipe smokers, Inductive coupled plasma mass spectrometry

Tropical Journal of Pharmaceutical Research is indexed by Science Citation Index (SciSearch), Scopus, International Pharmaceutical Abstract, Chemical Abstracts, Embase, Index Copernicus, EBSCO, African Index Medicus, JournalSeek, Journal Citation Reports/Science Edition, Directory of Open Access Journals (DOAJ), African Journal Online, Bioline International, Open-J-Gate and Pharmacy Abstracts

\section{INTRODUCTION}

Tobacco use is one of the main risk factors for a number of chronic diseases, including cancer, lung diseases, and cardiovascular diseases [1,2]. Numerous studies have been concern on smoking in Saudi Arabia population [3,4] Tobacco and their products contain many organic carcinogens in addition to toxic elements [5]. Some of these elements pass into the blood stream and may accumulate in specific organ [5] Smoking is an established source of toxic elements such as $\mathrm{Cd}, \mathrm{Hg}, \mathrm{As}, \mathrm{Pb}$ and $\mathrm{Ni}$, which are known to cause physiological disorders [7-9].

Studies have been carried out in various cities to determine the levels of toxic elements in smokers using either inductive coupled plasma (ICP)optical emission spectrometry [10] or ICP - mass spectrometry [11-15]. Most of the reported data 
[10-15] show that the concentrations of heavy metals in smokers are higher than in nonsmokers. The present investigation was aimed to assess the concentration of $\mathrm{Cd}, \mathrm{Pb}, \mathrm{As}, \mathrm{Hg}$ and $\mathrm{Ni}$ in the blood of cigarette smokers and tobacco pipe smokers resident in Riyadh, Saudi Arabia, using inductive coupled plasma mass spectrometry, after microwave acid digestion. An attempt was also made to draw a correlation between smoking and the concentration these toxic elements.

\section{EXPERIMENTAL}

\section{Chemical and reagents}

High-purity hydrogen peroxide $35 \%(\mathrm{w} / \mathrm{v})$ and analytical reagent grade nitric acid 69- $71 \%$ $(w / v)$, hydrochloric acid of purity $(36-38 \%)$ Riedel-de Haën, Seelze, Germany. High purity water used for diluting samples, blanks and standard was obtained using Water Purification System Type, PURELABE OPTION-Q15 of ELGA Lab Water, British. Standard solution of $\mathrm{Pb}, \mathrm{Cd}, \mathrm{As}, \mathrm{Hg}, \mathrm{Ni}$, and rhodium (Rh) of concentration of $1 \mathrm{mg} \mathrm{mL}^{-1}$ of Perkin Elmer was used.

\section{Apparatus}

Inductive coupled plasma mass spectrometry (ICP/MS) NexION 300D, the system manufactured by Perkin Elmer, New York, USA. The instrumental conditions are shown in Table 1. Deionized water was obtained using Water Purification System Type, PURELABE OPTIONQ15 from Elga Lab Water, British. A microwave digestion system manufactured by Milestone (Ethos One) Sorisole, Italy. The instrumental conditions are shown in Table 1.

Table 1: Operating conditions for inductive coupled plasma mass spectrometry

\begin{tabular}{ll}
\hline RF power & $1250 \mathrm{~W}$ \\
Nebulizer gas glow & $0.92 \mathrm{~L} / \mathrm{min}$ \\
Lens voltage & $9.25 \mathrm{~V}$ \\
Analog stage voltage & $-1762.5 \mathrm{~V}$ \\
Pulse stage voltage & $1050 \mathrm{~V}$ \\
Replicates per sample & 3 \\
Reading/replicates & 20 \\
Scan mode & Peak hopping \\
Dwell time & $40 \mathrm{~ms}$ \\
Integration & $1200 \mathrm{~ms}$ \\
Internal standard & Rhodium $500 \mathrm{ppb}$ \\
\hline
\end{tabular}

\section{Sample collection and pretreatment}

Blood samples were obtained from 30 cigarettesmoking volunteers (aged between 20 and 50 years, with the period of smoking ranging from 4 to 40 years). Blood samples for 30 tobacco pipe smoking volunteers (aged between 20 and 54 years, with a period of smoking ranging from 2 25 years); and for 24 non-smoking volunteers (aged 20 to 58 years) were also collected. All the volunteers were men resident in Riyadh City. The method was developed and validated for a clinical trial for determination of heavy metals and conducted in accordance with the Declaration of Helsinki [16] and approved by the Research Ethics Committee of Ministry of Health Riyadh, Saudi Arabia (approval ref no. 4810). Samples were collected and classified on the basis of the period of smoking; $5 \mathrm{ml}$ blood was withdrawn and placed in tubes containing lithium heparin $(8 \mathrm{ml})$, and placed in a refrigerator at a temperature of $-20{ }^{\circ} \mathrm{C}$ until analyzed.

\section{Preparation of standard solutions samples}

Two working solutions, each of 100 and 10 $\mu \mathrm{g} / \mathrm{mL}$, of $\mathrm{Cd}, \mathrm{Pb}, \mathrm{As}, \mathrm{Hg}, \mathrm{Ni}$ and $\mathrm{Rh}$ were prepared by suitable dilution of standard solution with de-ionized water.

\section{Sample digestion}

The blood sample $(0.75 \mathrm{ml})$ was transferred into a Teflon pots; $\mathrm{HNO}_{3}(2 \mathrm{ml}), 2 \mathrm{ml}$ of $\mathrm{H}_{2} \mathrm{O}_{2}$, and 8 $\mathrm{ml}$ of deionized water were added into each pot. The pots were placed in a microwave, closed, and heated to digest it according to the conditions shown in Table 2 [17]. After digestion, the samples were left to cool at room temperature $\left(25^{\circ} \mathrm{C}\right)$; the resulting solution filtered with Whatman No. 42 filter paper, transferred into a $50 \mathrm{ml}$ volumetric flask and filled to the mark with deionized water. Blank and standard solutions were prepared in a similar manner. The final sample solution was analyzed by ICP-MS.

\section{Validation of the proposed method}

Validation of the proposed method was performed using ICP-MS for analysis of heavy metals in cigarette, tobacco pipe and non-smoker blood samples. The validation parameters including linearity, sensitivity, selectivity, precision, and accuracy were examined. The proposed method was checked by adding known concentration of the tested elements in deionized water. Also the proposed method was tested by applying of the proposed method to analysis of the study elements in certified reference material (KATS no. 2008242) [18].

\section{Statistical analysis}

The results are presented as mean \pm standard deviation (SD) and were analyzed by one-way 
analysis of variance (ANOVA). Statistical significance was set at $p<0.05$, and analysis was carried out using Microsoft Excel for Windows 2010 and Statistical Package for the Social Sciences (SPSS), version 16.0.

\section{RESULTS}

After digestion in microwave, ICP-MS allows for the simultaneous determination of $\mathrm{Cd}, \mathrm{Pb}, \mathrm{As}$, $\mathrm{Hg}$ and $\mathrm{Ni}$ at low concentrations in the blood. The optimum conditions for ICP - MS were obtained, viz, good linearity, correlation coefficient, accuracy and precision. Calibration curves were obtained in the range of $10-100 \mu \mathrm{g} / \mathrm{L}$ for cadmium, lead, arsenic and nickel, nickel [19]. Mercury was in the range of $100-300 \mu \mathrm{g} / \mathrm{L}$. All calibrations were carried out using rhodium as internal standard [19]. The regression equation of the calibration curves were $y=6218.4 x-1424$. 1 , $y=4017.7 x-202.53, y=5745.6 x+8050.6, y=$ $1174 x+2400$ and $y=10002 x+335.44$ for $\mathrm{Cd}$, $\mathrm{Pb}, \mathrm{As}, \mathrm{Hg}$ and $\mathrm{Ni}$, respectively, where the correlation coefficient $\left(r^{2}\right)$ were 0.9999, 0.99919, $0.9992,0.9989$ and 0.99992 respectively. Mean recovery was 97.37, 98.9, 101.95, 95.0 and $103.13 \%$ for $\mathrm{Cd}, \mathrm{Pb}, \mathrm{As}, \mathrm{Hg}$ and $\mathrm{Ni}$ respectively. The relative standard deviation was 4.6, 1.5, 1.2, 6.2 and $1.7 \%$ for $\mathrm{Cd}, \mathrm{Pb}, \mathrm{As}, \mathrm{Hg}$ and $\mathrm{Ni}$, respectively (Table 3 ). On the other hand, analysis of the certified sample by the proposed method showed that recovery was 100.77, 102.67, 104.01, 95.0 and $102.92 \%$ for $\mathrm{Cd}, \mathrm{Pb}$, As, $\mathrm{Hg}$ and $\mathrm{Ni}$, respectively, while relative standard deviation was 4.7, 3.3, 5.2, 6.2 and 3.1 $\%$ for $\mathrm{Cd}, \mathrm{Pb}, \mathrm{As}, \mathrm{Hg}$ and $\mathrm{Ni}$, respectively (Table 4).
Table 5: ANOVA data

\begin{tabular}{lcc}
\hline Element & F-test & $\boldsymbol{P}$-value \\
& & \\
\hline $\mathbf{C d}$ & 6.810 & 0.002 \\
$\mathbf{P b}$ & 22.409 & 0.000 \\
$\mathrm{As}$ & 4.807 & 0.011 \\
$\mathrm{Hg}$ & 161.288 & 0.000 \\
$\mathrm{Ni}$ & 29.197 & 0.000 \\
\hline
\end{tabular}

\section{DISCUSSION}

In this study, we determine the concentration of toxic metals ( $\mathrm{Pb}, \mathrm{Cd}, \mathrm{As}, \mathrm{Hg}$ and $\mathrm{Ni}$ ) in blood samples of cigarette, tobacco pipe, and nonsmokers using ICP-MS method to determine any correlation between toxic metals concentration and smoking habitats. The developed ICP-MS was validated by analysis of standard sample and spiking known concentration of toxic metals. The validated method showed good linearity, accuracy, precision and lower limit of detection.

Smoking is one of the major sources of intake of the toxic element [5]. The tobacco absorb the element mainly form soil or from the environment. Toxic elements pass into the blood stream and accumulate in kidneys, which damage their ability to regulate the water balance in the body. This function (water unbalance), lead to water retention and salt retention. Therefore many dieses like blood pressure [6] and cardiovascular disease [1] were occurred. On the other hand, smoking causes the inhalation of cadmium, arsenic, nickel and mercury.

Nickel vapor reacts with carbon monoxide in tobacco to form carcinogenic carbonyl compounds [5].

Table 3: Determination of heavy metal concentrations in spiked de-ionized water using ICP-MS

\begin{tabular}{lccccc}
\hline Element & Added $(\mu \mathrm{g} / \mathrm{L})$ & Found $(\mu \mathrm{g} / \mathrm{L})$ & Recovery $(\%)^{\star}$ & SD & RSD (\%) \\
\hline $\mathbf{C d}$ & 6.47 & 6.30 & 97.37 & 0.29 & 4.6 \\
$\mathbf{P b}$ & 18.15 & 17.95 & 98.89 & 0.26 & 1.5 \\
$\mathrm{As}$ & 56.02 & 57.11 & 101.94 & 0.69 & 1.2 \\
$\mathrm{Hg}$ & 40.0 & 38 & 95.00 & $0.00^{\prime}$ & 6.2 \\
$\mathrm{Ni}$ & 58.1 & 59.92 & 103.1 & 1.02 & 1.7 \\
\hline
\end{tabular}

Table 4: Heavy metal levels in certified sample, etermined by ICP-MS

\begin{tabular}{lcccc}
\hline Element & $\begin{array}{c}\text { Recommended } \\
\text { value }(\mathbf{m g} / \mathbf{k g})\end{array}$ & $\begin{array}{c}\text { Measured value } \\
(\mathbf{m g} / \mathbf{k g})\end{array}$ & Recovery (\%) & RSD (\%) \\
\hline $\mathbf{C d}$ & 1.3 & 1.31 & $100.77 \pm 0.06$ & 4.7 \\
$\mathbf{P b}$ & 60 & 61.6 & $102.77 \pm 2.03$ & 3.3 \\
$\mathbf{A s}$ & 13.4 & 0.73 & $104.01 \pm 0.73$ & 5.2 \\
$\mathbf{H g}$ & 0.04 & 0.038 & $95.00 \pm 0.002$ & 6.2 \\
$\mathbf{N i}$ & 26 & 26.76 & $102.92 \pm 0.83$ & 3.1 \\
\hline
\end{tabular}

*Mean of five determinations 
Exposure to mercury causes damage to brain [21], while arsenic causes damage to nerve cells in patients suffering from diabetes and heart disease, and to blood vessels [22]. Smoking, in some circumstances, may lead to cancer diseases, especially prostate cancer, based on varying mechanisms, for example, increase in total and free testosterone, genetic variation, carcinogenic effect [23].

The results obtained in the present study show that mean blood cadmium, lead and nickel concentration were higher in smokers than in non-smokers, and are higher than those previously reported by other workers [24,25]. On the other hand, the mercury and arsenic reported for both smokers and non-smokers in the present study are in accord with an earlier report [24].

To find a correlation between the toxic metals and smoking habitat and non-smokers, variance test has been carried out using statistical analysis. The significance of toxic elements $(\mathrm{Cd}$, $\mathrm{Pb}$, As, $\mathrm{Hg}$, and $\mathrm{Ni}$ ) were smaller than the significance off null hypothesis. Therefore there are significance difference between the concentration of toxic metals in smokers and non-smokers. These findings are in agreement with previous studies [10-15].

Thus, the findings obtained indicate that toxic metal blood levels are much higher in smokers than in non-smokers. Health care professionals need to offer appropriate counsel and therapies to patients suffering from ailments such as blood pressure [10,11], cardiovascular diseases [1], Alzheimer's diseases [13] and prostate cancer [15].

\section{CONCLUSION}

Inductive coupled plasma-mass spectrometry has been developed for the determination of $\mathrm{Cd}$, $\mathrm{Pb}, \mathrm{As}, \mathrm{Hg}$, and $\mathrm{Ni}$ in cigarette, tobacco pipe and non-smokers smokers in Saudi Arabia (population). The study shows that the concentration of heavy metals in smokers is much higher than non-smokers. The findings of this study lend some support to the link between heavy metals in human body and smoking habitat.

\section{DECLARATIONS}

\section{Acknowledgement}

The authors extend their appreciation to the Deanship of Scientific Research at King Saud
University for funding the work through the Research Group Project no. RGP-1436-024.

\section{Conflict of Interest}

No conflict of interest associated with this work.

\section{Contribution of Authors}

The authors declare that this work was done by the authors named in this article and all liabilities pertaining to claims relating to the content of this article will be borne by them.

\section{Open Access}

This is an Open Access article that uses a funding model which does not charge readers or their institutions for access and distributed under the terms of the Creative Commons Attribution License (http://creativecommons.org/ licenses/by/4.0) and the Budapest Open Access Initiative (http://www.budapestopenaccessinitiati ve.org/read), which permit unrestricted use, distribution, and reproduction in any medium, provided the original work is properly credited.

\section{REFERENCES}

1. Nawrot T, Thijs L, Den Hond E, Roels H, Staessen JA. An epidemiological re-appraisal of the association between blood pressure and blood lead: a metaanalysis. J. Hum Hypertens.2002; 16: 123-131.

2. Witte $K K$, Nikitin NP, Parker AC, Von Haehling S, Volk $H$ $D$, Anker $S D$. Clark AL, Cleland JG, The effect of micronutrient supplementation on quality-of-life and left ventricular function in elderly patients with chronic heart failure. Eur Heart J.2005; 26: 2238 -2244.

3. Alanazi A, Al Enezi F, Alqahtani MM, Alshammari TF, Ansari MA, Al-Oraibi S, Qureshi S. Effects of passive smoking on students at College of Applied Medical Sciences, King Saud Bin Abdulaziz University for Health Sciences. J Nat Sci Biol Med. 2015; 6: 100-105.

4. BinSaeed AA. Asthma control among adults in Saudi Arabia: Study of determinants. Saudi Med J. 2015; 36: 599-604.

5. Chiba M, Masironi R. Toxic and trace elements in tobacco and tobacco smoke. Bull World Health Organ 1992; 70: 269 -275

6. Momčilović B. "Reilly C. Metal Contamination of Food. Its significance for food quality and human health. Oxford: Blackwell Science Ltd. 2002 (ISBN 063205927 3). Croatian Medical Journal, 2003; 44:506-507.

7. Kazi TG, Jalbani N, Kazi N, Jamali M K, Arain MB, Afridi HI, Kandhro A, Pirzado Z. Evaluation of toxic metals in blood and urine samples of chronic renal failure patients, before and after dialysis. Renal Failure 2008; 30: 737-745.

Trop J Pharm Res, December 2016; 15(12): 2672 
8. Kazi T, Memon A, Afridi $H$, Jamali M, Arain M, Jalbani $N$, Sarfraz $R$, Determination of cadmium in whole blood and scalp hair samples of Pakistani male lung cancer patients by electrothermal atomic absorption spectrometer. Sci Total Environ 2008; 389: 270-276.

9. Fitzpatrick TM, Blair EA. Upper airway complications of smoking. Clinics in chest medicine 2000; 21: 147-157.

10. Massadeh A, Gharibeh A, Omari K, Al-Momani I, Alomari $A$, Tumah $H$, Hayajneh $W$. Simultaneous determination of $\mathrm{Cd}, \mathrm{Pb}, \mathrm{Cu}, \mathrm{Zn}$, and $\mathrm{Se}$ in human blood of Jordanian smokers by ICP-OES. Biol. Trace Elem. Res 2010; 133: 1-11.

11. Afridi HI, Kazi TG, Talpur FN, Brabazon D, Naher S. Estimation of toxic elements in the samples of different cigarettes and their impact on human health of Irish hypertensive consumers. Clin Chim Acta 2013; 426: 51 57.

12. Cogun HY, Firat O. Cadmium Levels in Hair and Nail of Smoking and Non Smoking. Ekoloji 2013; 22: 80-88.

13. Lee J-Y, Kim J-H, Choi D-W, Lee D-W, Park J-H, Yoon $\mathrm{H}$-J, Pyo H-S, Kwon H-J, Park K-S, The association of heavy metal of blood and serum in the Alzheimer's diseases. Toxic Res 2012; 28: 93-98.

14. Tian $Y$, Hou $H$, Zhu $F$, Wang A, Liu $Y$, Hu $Q$, Simultaneous Determination of Chromium, Cadmium, and Lead and Evaluation of the Correlation between Chromium and Cotinine in Chinese Smokers. Biol.Trace Elem. Res. 2014; 158: 9-14.

15. Neslund-Dudas C, Kandegedara A, Kryvenko ON, Gupta $N$, Rogers C, Rybicki BA, Dou QP, Mitra B, Prostate tissue metal levels and prostate cancer recurrence in smokers. Biol. Trace Elem. Res.2014; 157: 107-112.

16. Ethical principles for medical research involving human subjects. Revised October 2013. World Medical Association Declaration of Helsinki [online] (http://www.wma.net/en/30publications/10policies/b3/ind ex.html.pdf?print-media-type\&footerright=[page]/[toPage], [accessed 10 Oct 2016].

17. Schweitzer L, Cornett C. Determination of Heavy Metals in Whole Blood Using Inductively-Coupled Plasma-Mass Spectrometry: A Comparison of Microwave and Dilution Techniques. The Big M 2008; 4: 75-83.

18. Mackey E, Christopher S, Lindstrom R, Long S, Marlow A, Murphy K, Paul R, Popelka-Filcoff R, Rabb S, Sieber $J$. Certification of three NIST renewal soil standard reference materials for element content: SRM 2709a San Joaquin Soil, SRM 2710a Montana Soil I, and SRM 2711a Montana Soil II. NIST Special Publication 2010, 260: 172: 1- 39.

19. Miller JN, Miller JC. Statistics and chemometrics for analytical chemistry. Pearson Education 1986; pp 33-79.

20. Armitage $P$, Berry G, Matthews J, Survival analysis. Statistical Methods in Medical Research, 4th edn, 1994; pp 568-590.

21. Clifton JC, Mercury exposure and public health. Pediatric Clinics of North America 2007; 54: 237-269.

22. Carlson-Lynch H, Beck BD, Boardman PD. Arsenic risk assessment. Environ Health Perspect. 1994, 102:354356.

23. Zu K., Giovannucci E. Smoking and aggressive prostate cancer: a review of the epidemiologic evidence. Cancer Cause Control, 2009; 20: 1799-1810.

24. Roberts WL, Moulton L, Law TC, Farrow G, CooperAnderson M, Savory J, Rifai N. Evaluation of nine automated high-sensitivity $C$-reactive protein methods: implications for clinical and epidemiological applications. Part 2. Clin. Chem. 2001; 47: 418-425.

25. LYON F, IARC monographs on the evaluation of carcinogenic risks to humans. 2014; pp 1-54. 